\title{
Adding Kaffir Lime (Citrus hystrix) Leaf Essential Oil to Gelatin Coating for Extending the Shelf Life of Red Snapper Fillet
}

\author{
Ika Febriana, Endang Dewi Mashithah", and Heru Pramono \\ Department of Marine Science, Faculty of Fisheries and Marine, Universitas Airlangga, Surabaya, East Java, Indonesia \\ *Corresponding author's Email: endang-d-m@fpk.unair.ac.id; (DORCiD: 0000-0002-8148-8567
}

\begin{abstract}
Red Snappers contain high content protein and water which makes them highly perishable. However, they are widely processed into the fillet. One of the disadvantages of filleting is the short shelf life due to the high water content turning the fillets into an ideal media for bacteria. The edible coating protects the meat from perishability by reducing the water vapor, aroma, and lipid migration. One of the potential protein sources for coating is gelatin. The essential oil content that has a role in inhibiting bacterial growth is citronellal. The present study aimed to determine the effects of adding Kaffir limes (Citrus hystrix) leaf essential oil to a gelatin coating on the shelf life of red snappers' fillet. An experiment was conducted using a completely randomized design with four treatment groups based on the concentration of Citrus hystrix essential oil and five replications ( $\mathrm{n}=3$ per group). In this regard, the treatments were named $\mathrm{P}_{0}(0 \%$ of Citrus hystrix $), \mathrm{P}_{1}(1 \%$ of Citrus hystrix $), \mathrm{P}_{2}\left(1.5 \%\right.$ of Citrus hystrix), and $\mathrm{P}_{3}(2 \%$ of Citrus hystrix). The investigated parameters included total plate count, sensory quality, and acidity. Data analysis was performed using ANOVA followed by Duncan's multiple range test. The results showed that the addition of $1.5 \%$ and $2 \%$ Citrus hystrix essential oil decreased the number of bacteria, and led to a higher sensory quality. In conclusion, The addition of Citrus hystrix essential oil in the gelatin-coating process can be used as a method of processing the fishery products to extend the shelf life of red snappers' fillet at room temperature and inhibit bacterial growth.
\end{abstract}

Keywords: Edible coating, Kaffir lime leaf, Red snapper fillet

\section{INTRODUCTION}

Red snappers are one of the demersal fishes widely found in Indonesian marine waters. It is consumed by many people, and it has high economic value. In 2007, the production of red snappers in Indonesia was 116.994 tons with an average increase of $4.83 \%$ each year for export commodities (Kelautan and Indonesia, 2018). Basically, red snappers have a relatively higher growth rate, compared to other marine fish. It is a fishery commodity that has the prospect of supporting cultivation development in the future (Dance and Rooker, 2019).

Red Snappers contain high content protein and water which makes them highly perishable. To fulfill the needs of the consumers who always desire fresh fish, it is important for good fish handling. One of the fish handling steps leading to fresh products is processing the fish to the fillet. Red snappers are widely processed into fillets which is a raw material for the Seafood processing industries. Processing fillet of red snappers produces fish skin with a yield of $8.7 \%$ of the total weight of the fish. The fillet is a product favored by people, which requires easy handling and can be processed into various products (Shahiri Tabarestani et al., 2016).

One of the disadvantages of filleting is its short shelf life due to its high water content, which is an ideal medium for decomposing bacteria (Sohaib et al., 2016). Therefore, it is of utmost importance to extend the shelf life of the fillet leading to a better consumption condition. Fillet storage at a low temperature can extend shelf life by inhibiting decomposer microbial growth. Besides, the addition of anti-microbial material is also expected to extend the shelf life (Indrasti et al., 2012). The edible coating is defined as a thin layer used for coating edible food products. This layer protects the product from mechanical perishability by reducing the water vapor, aroma, and lipid migration in the packaged food (Siburian, 2016). The edible coating could be produced from three materials, namely hydrocolloids (protein and polysaccharides), lipids, and composites. Hydrocolloids as the edible coating have several advantages including good mechanical properties, suitable food protection from lipids and hydrophobic, and an efficient barrier to oxygen and carbon dioxide (Arvanitoyannis, 2007). Based on its composition, hydrocolloid consists of polysaccharides and proteins. The potential protein source for edible coating is gelatin (Jongjareonrak et al., 2006).

Gelatin is a derivative compound produced from collagen fibers in connective tissue that is hydrolyzed with acids or bases. This means gelatin could be produced from ingredients that are rich in collagen, such as pig, cattle, or other animals' skin and bones (Munda, 2013). Gelatin is a simple protein produced by collagen hydrolysis which is watersoluble, while collagen is water-insoluble. Gelatin is widely used as cosmetic ingredients, pharmaceutical products, food additives (ice cream, gum, and thickener), film materials, medical materials, and raw materials for microorganism 
culture. Physically, gelatin is solid, dry, tasteless, and transparent (Jongjareonrak et al., 2006). The protein with its specific structure is composed of 20 different amino acids, and is influenced by the covalent bonds that are not present in polysaccharides (Jongjareonrak et al., 2006). Gelatin edible coating could be used to extend the shelf life of fresh fish filleting (López-Caballero et al., 2006).

The main components of Kaffir lime leaf essential oil include citronellal (81.49\%), citronellol (8.22\%), linalool (3.69\%), geraniol $(0.31 \%)$, and other substances (6.29\%) (Ayusuk et al., 2009). The essential oil content that has the most important role in inhibiting bacterial growth is citronellal. Citronellal as an antioxidant and antibacterial is capable of inhibiting the growth of Salmonella and other Enterobacteriaceae (Nanasombat, 2005; Ayusuk et al., 2009). The pure extracts of kaffir lime leaf are commonly rare, but along with the development of the food beverage and flavor industries, kaffir lime leaf essential oil is a potential alternative. Citronellal compounds have different structures at the bacterial cell walls leading to their perishability (Yuliani et al., 2011). The cell wall acts as a cell-forming, and it protects cells against osmotic lysis. Substances that damage the cell wall or block synthesis can induce cells lysis and bacterial death.

Current study was aimed to determine the effects of the addition of Kaffir lime leaf essential oil (Citrus hystrix) supplemented with different concentrations of edible coating gelatin on the shelf life of red Snappers' (Lutjanus sp.) fillet.

\section{MATERIALS AND METHODS}

\section{Materials}

Kaffir lime leaf essential oil was obtained from the distillation industry in Yogyakarta, Indonesia, and gelatin was purchased from a bakery store. The mixtures were prepared by the addition of $8 \mathrm{~g}$ of gelatin to $100 \mathrm{ml}$ of aquadest and $0 \%, 0.5 \%, 1 \%$, and $2 \%$ of essential oil (Alparslan et al., 2016). This is the optimum concentration to inhibit bacterial growth for shrimp products, while the best concentration for fillet products has not been yet documented. The four treatments added to the red snappers' fillet coatings were named $\mathrm{P}_{0}(0 \%$ of Citrus hystrix $), \mathrm{P}_{1}\left(1 \%\right.$ of Citrus hystrix), $\mathrm{P}_{2}$ ( $1.5 \%$ of Citrus hystrix), and $\mathrm{P}_{3}(2 \%$ of Citrus hystrix).

The condition of the investigated fish samples was as followed: bright and protruding out eyes, firm and supple meat, bright and red gills, bright and strong attached scales, mucusless skin, and fresh smell that is specific to the fish species (Nasional, 2006). The red snappers' fillets were sized $4 \times 7 \mathrm{~cm}$.

The filleting was started with the knife movement from the back of the pectoral fin with the fish facing left and blade facing right. Then, the knife was moved slowly along the bone from head to tail until the meat was separated from the bone.

\section{Material and Methods}

\section{Edible coating formulations}

The edible coating was prepared using $100 \mathrm{ml}$ of aquadest, heated in a hot plate until the temperature reached $\pm 80^{\circ} \mathrm{C}$, and the temperature was controlled by a thermometer (Alparslan et al., 2016). In the next step, $8 \mathrm{~g}$ of gelatin was gradually added, and stirred by a magnetic stirrer for \pm 15 minutes at $\pm 80^{\circ} \mathrm{C}$. Gliserol $(0.15 \mathrm{ml}$ per gram of gelatin $)$ was added to the gelatin solvent as a plasticizer. The kaffir lime leaf essential oil at the ratios of $1 \%, 1.5 \%$, and $2 \%$ (volume per mass of gelatin) was added to the coating solvent. To stabilize the emulsion in the essential oil, Tween- 80 (Polysorbate $80^{\circledR}$ ) was added into the gelatin solvent with a ratio of $0.2 \%$ essential oil.

The edible coating was applied to the red snapper fillets using the dipping method (Alparslan et al., 2016). The dipping method was performed by dipping or soaking all parts of the food in the edible coating. Before use, the edible coating solvent was warmed to a temperature of $\pm 50^{\circ} \mathrm{C}$. Clean red snappers' fillets were dipped in an edible coating solvent for 30 seconds twice and got drained. Then, the red snapper fillets were stored at room temperature for 24 hours.

\section{Organoleptic test}

Regarding the quality assessment, the organoleptic test has an important role as an initial detector to recognize product changes (Nasional, 2006) by addressing the appearance, odor, flesh, and texture of a product. The sheets used in the organoleptic test were based on Standar Nasional Indonesia (SNI) 01-2696.1-2006. The panelists of this study were 30 untrained students studying at the Faculty of Fisheries and Marine Airlangga University. Therefore, the findings of the organoleptic test could be subjective, since it only relied on the panelists' sense and sensitivity ( Adawyah, 2007).

\section{Calculation of the total of bacteria}

The microbial test was held by determining the Total Plate Count (TPC, Nugraheni, 2013). The TPC was determined by calculating the total bacterial cells in the Petri dish, and comparing it with quality standards. The 
maximum limits of microbe for red snapper fillets were 5×10-5 colony/g (Nasional, 2006; Adawyah, 2007).

The TPC method was performed by multilevel dilution. Multilevel dilution was conducted by grinding one gram of catfish fillet in $9 \mathrm{ml}$ of sterile physiological $\mathrm{NaCl}$ solvent in a ratio of 1: 9 until the mixture was homogeneous, a solvent with the dilution of 10-1 was obtained. Afterwards, $1 \mathrm{ml}$ of the dilution suspension of 10-1 was taken by a 10-mililiter volume sterile pipette. Then, it was put into a test tube containing $9 \mathrm{ml}$ of sterile physiological $\mathrm{NaCl}$ solvent, and homogenized to obtain a dilution of 10-2, followed by higher dilution. The number of dilutions was five adjusted to the requirements of the study $\left(10^{-1} 10^{-2}, 10^{-3}, 10^{-4}\right.$, and $\left.10^{-5}\right)$ (Florensia et al., 2012).

The TPC calculation or fertilizing activities were carried out by a pouring method through which one $\mathrm{ml}$ of the diluted sample was taken using a 10-milliliter volume sterile pipette from the dilution tube, and transferred into two sterile Petri dishes in duplicate. The suitable time during dilution (starts until pouring into the petri dish) was around 30 minutes, normally (Fardiaz, 1993). Sterile plate count agar (PCA) media (which was cooled to $50^{\circ} \mathrm{C}$ ) was put into $15 \mathrm{ml}$ of the petroleum oil. The Petri dish poured in PCA media was spread on the table in a circular motion or movement similar to the number eight, then it was let stand until the agar media in the petri dish was solidified (Fardiaz, 1993). The Petri dish was incubated in an incubator at $37^{\circ} \mathrm{C}$ for 24 hours with a reversed position of the Petri dish (Florensia et al., 2012) due to alkaline compounds, such as ammonia, trimethylamine, and other volatile compounds (Adawyah, 2007).

\section{Analysis of proximate \\ pH analysis}

The acidity $(\mathrm{pH})$ of the red snapper fillet was measured by dissolving three grams of the sample with $50 \mathrm{ml}$ of the sterile aquadest according to Souza et al., (2010). The samples were homogenized, and then the $\mathrm{pH}$ value was measured using a $\mathrm{pH}$ meter. Rotten fish meat has a high $\mathrm{pH}$ value due to the emergence of alkaline compounds, such as ammonia, trimethylamine, and other volatile compounds Adawyah, 2007).

\section{Moisture analysis}

Water content was determined using an oven. Aluminum plates were dried in an oven for 30 minutes at a temperature of $100-105^{\circ} \mathrm{C}$. The cup was cooled in a desiccator for 30 minutes, and immediately weighed. A sample of five $\mathrm{g}$ was put into a cup and weighed, then the cup containing the sample was dried in an oven at a temperature of 100$105^{\circ} \mathrm{C}$ for about 6 hours until a constant weight was reached, the cup was cooled in a desiccator for about 30 minutes, and immediately weighed (Standar Nasional Indonesia, 1992).

\section{Ash content analysis}

To conduct the analysis in according to Harris and Marshall (2017), 2.0-3.0 g of the samples were put into a porcelain dish and burned on the burner until the smoke ran out. Next, the sample was put into the furnace at $600^{\circ} \mathrm{C}$ for 4-5 hours. After that, the sample was inserted into the desiccator, and got weighed.

\section{Protein content analysis}

In this phase of the study, 1.0-2.0 $\mathrm{g}$ of the samples were put into a $100 \mathrm{ml} \mathrm{Kjeldahl} \mathrm{flask.} \mathrm{Then,} 1.0 \mathrm{~g}$ of $\mathrm{K}_{2} \mathrm{SO}_{4}, 40$ $\mathrm{mg}$ of $\mathrm{HgO}$, and $2.0 \mathrm{ml}$ of concentrated $\mathrm{H}_{2} \mathrm{SO}_{4}$ were added to the flask. After that, it was reconstructed until the liquid was clearly green. Next, $10 \mathrm{ml}$ of $60 \% \mathrm{NaOH}$ and $5 \% \mathrm{Na}_{2} \mathrm{~S}_{2} \mathrm{O}_{3}$ were added, and then distilled (Hart and Fisher, 1971). The distillation results were accommodated in an Erlenmeyer flask containing $5 \mathrm{ml} \mathrm{of} \mathrm{H}_{3} \mathrm{BO}_{3}$ and 2-4 red methyl and methyl blue drops to obtain about $15 \mathrm{ml}$ of distillate. The obtained distillate was titrated with standard $0.02 \mathrm{~N} \mathrm{HCl}$ until the endpoint.

\section{Lipids content analysis}

The fat flask which using in the Soxhlet extraction tool was dried in the oven, then cooled in the desiccator, and got weighed. Samples were weighed and then wrapped in filter papers, and inserted into the Soxhlet extraction tool. The hexane solvent was put into a fat flask based on the size of the soxhlet extraction tool used in the current study. In the next step, the reflux was carried out for five hours. Furthermore, the fat pumpkin containing the extracted fat was heated in the oven at $105^{\circ} \mathrm{C}$. Next, it was cooled in the desiccator, and then it was weighed (Hart and Fisher, 1971).

\section{Statistical analysis}

Data analysis was performed by Analysis of Variance (ANOVA) followed by Duncan's multiple range test in the SPSS software (version 22). P value less than 0.05 was considered statistically significant.

\section{RESULTS}

\section{Calculating the number of bacteria}

The results of calculating the total number of bacteria on the red snappers' fillet using the TPC method are shown in table 1. As can be seen in Table 1, the average total number of bacteria on the red snapper fillet of each treatment increased every hour during the storage process, and it reached its highest number at the end of the storage. The highest average total number of produced bacteria at 0 (initial) to 24 (final) hours in P0 (control) was reported $1.77 \times 10^{3}$ to 
$2.72 \times 10^{6}$. On the other hand, the lowest average total number of bacteria at 0 (initial) to 24 hours (final) was produced in the second treatment $\left(1.5 \%\right.$ kaffir lime leaf essential oil) and was measured $1.92 \times 10^{3}$ to $2.1 \times 10^{6}$. The obtained results of ANOVA showed that there were significant differences between the treatment groups including kaffir lime leaf essential oil and the one without kaffir lime leaf essential oil $(\mathrm{p}<0.05)$.

\section{pH value}

The $\mathrm{pH}$ value of fishery products is an important quality indicator (Mursida, 2013). The $\mathrm{pH}$ testing was performed to determine the freshness of the fish. The $\mathrm{pH}$ values of red snapper fillets are shown in table 2 . The $\mathrm{pH}$ value of each treatment decreased from the beginning to the end of the storage. The $\mathrm{pH}$ value of the addition of kaffir lime leaf essential oil had a significant effect on hours 12,18 , and 24 in all treatments $(\mathrm{p}<0.05)$, and had no significant effect on hours 0 and 6 in all treatments $(\mathrm{p}>0.05)$.

Table 1. Average total number of bacteria $\left(\mathrm{CFU}^{*} /\right.$ gram) on red snapper fillets

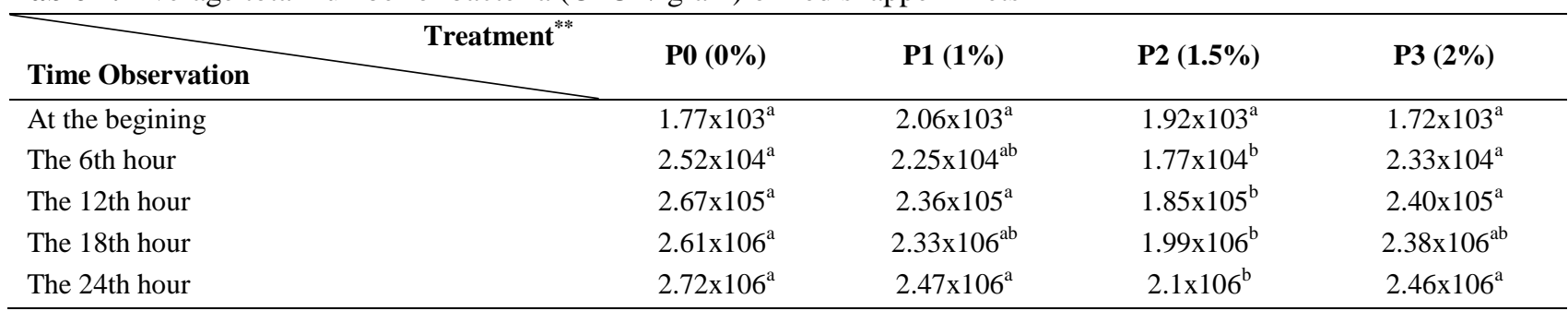

Note: The notation indicated by different superscript letters in the same column shows that the comparison among the treatments has a significant difference ( $\mathrm{p}<0.05$ ). CFU: Colony-forming unit, $\mathrm{P}_{0}: 0 \%$ of Citrus hystrix, $\mathrm{P}_{1}: 1 \%$ of Citrus hystrix, $\mathrm{P}_{2}: 1.5 \%$ of Citrus hystrix, and $\mathrm{P}_{3}: 2 \%$ of Citrus hystrix

Table 2. Average $\mathrm{pH}$ value of red snapper fillets subjected to Kaffir Lime treatment

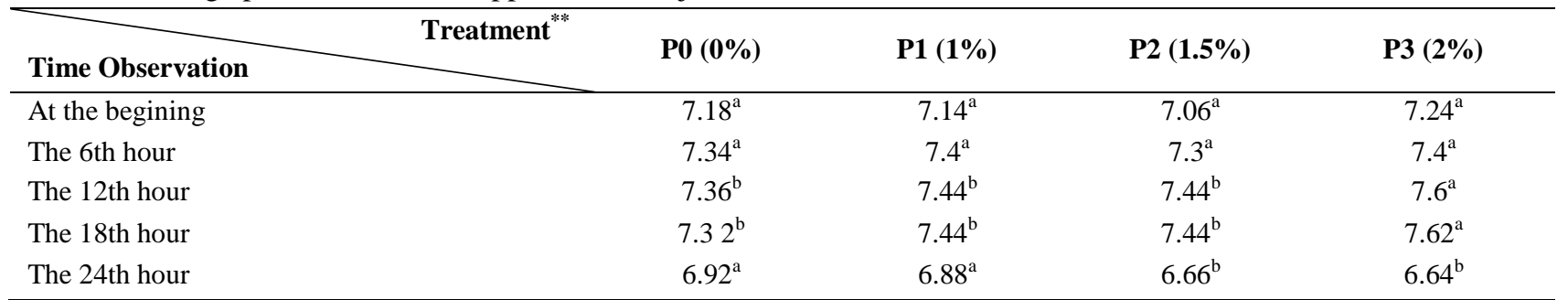

Note: The notation indicated by different superscript letters in the same column shows that the comparison among the treatments has a significant difference ( $\mathrm{P}<0.05) . \mathrm{P}_{0}: 0 \%$ of Citrus hystrix, $\mathrm{P}_{1}: 1 \%$ of Citrus hystrix, $\mathrm{P}_{2}: 1.5 \%$ of Citrus hystrix, and $\mathrm{P}_{3}: 2 \%$ of Citrus hystrix

Table 3. Organoleptic test of red snapper fillets subjected to Kaffir Lime treatment

\begin{tabular}{|c|c|c|c|c|c|c|c|c|}
\hline $\begin{array}{ll}\text { Parameter } & \text { Treatment } \\
\end{array}$ & \multicolumn{2}{|c|}{ P0 (0\%) } & \multicolumn{2}{|c|}{ P1 (1\%) } & \multicolumn{2}{|c|}{ P2 $(1.5 \%)$} & \multicolumn{2}{|c|}{ P3 (2\%) } \\
\hline Hours & $\mathbf{0}$ & 24 & 0 & 24 & 0 & 24 & 0 & 24 \\
\hline Appearance & 9.2 & 3 & 8 & 3.8 & 8.63 & 4.26 & 8.4 & 4.3 \\
\hline Smell & 9.2 & 3 & 8.4 & 3.4 & 8.8 & 3.8 & 7.8 & 4.06 \\
\hline Texture & 9.2 & 3 & 8.967 & 3.7 & 8 & 3.5 & 7.8 & 3.5 \\
\hline
\end{tabular}

$\mathrm{P}_{0}: 0 \%$ of Citrus hystrix, $\mathrm{P}_{1}: 1 \%$ of Citrus hystrix, $\mathrm{P}_{2}: 1.5 \%$ of Citrus hystrix, and $\mathrm{P}_{3}: 2 \%$ of Citrus hystrix

\section{Organoleptic test}

The organoleptic test on red snapper fillets included three parameters, namely appearance, odour, and texture. The appearance parameters encompassed values of 9 (specific color type, brilliant), 7 (specific color type, less brilliant), 5 (starting to change color, dull), 3 (edge slightly green, dull), and 1 (even green color). The odor parameters entailed values of 9 (fresh, specific type), 7 (neutral), 5 (musty and slightly rancid), 3 (sour, slight smell of ammonia, rancid), and 1 (smell of ammonia and rot). The texture parameters included values of 9 (solid, compact, and elastic), 7 (solid, less compact, and less elastic), 5 (slightly mushy, less elastic, and slightly runny), 3 (mushy, not elastic, and runny), and 1 (very soft and runny). Data related to the organoleptic test from the beginning to the end of the study are shown in Table 3.

The result of the appearance parameter of the red snapper fillet at the beginning of the study (P0 treatment named control) had a value of 9.2 which indicated that the color of the red snapper was specific and bright. The Pl (1\% essential oil), P2 (1.5\% essential oils), and P3 (2\% essential oils) had an average value of eight which revealed that red snapper fillets had a specific color, and were bright. However, the appearance parameter of P0 treatment (control) had a value of 
three at the end of the study indicating slightly greenish and dull red snapper fillets. The treatment groups of Pl (1\% essential oil), P2 (1.5\% essential oil), and P3 (2\% essential oil) had an average value of four, which was indicative of slightly flabby, less elastic, and slightly runny red snapper fillets. Accordingly, P1 and P3 had the lowest parameter values at the beginning of the study, whereas the lowest value was obtained in the treatment without the addition of essential oils (P0) at the end of the study.

The results of the organoleptic test for odor parameter at the null hour (initial) had a value of nine showing that the fillets were the fresh and specific type. The P1 (1\% essential oil) and P2 (1.5\% essential oil) treatments had an average value of eight indicating that fillets were the fresh and specific type. The samples in the P3 group (2\% essential oil) were scored seven which means that the odor was neutral. At the end of the study, P0 (control) and Pl (1\% essential oil) had an average value of three indicating an acidic odor, a little smell of ammonia, and rancid. The P2 (1.5\% essential oil) and P3 (2\% essential oil) treatments with an average value of four showed a slightly rancid and musty odor. A high odor value was observed at the beginning of the study (null hour) in P0, P1, and P2 treatments. On the other hand, P2 and P3 had a high odor value at the 24 th hour.

The results of the texture test at the null hour in P0 (control) and Pl (1\% essential oil) were reported a value of nine (solid, compact, and elastic). The P2 (5\% essential oil) had a value of eight indicating a solid, compact, and elastic texture. The P3 (2\% essential oil) with a value of seven was indicative of a solid, less compact, and less elastic texture. The P3 (2\% essential oil) had the lowest value.

At the end of the study, P0 (control), P2 (1.5\% essential oil), and P3 (2\% essential oil) had a value of three showing a non-elastic and runny texture. The samples in the Pl treatment group (1\% essential oil) had a value of four showing a slightly mushy, less elastic, and slightly runny texture. Accordingly, the P1 treatment group (1\% essential oil) had the highest value.

\section{Analysis of proximate}

Table 4 shows the proximate chemical composition of red snapper fillets consisting of water, protein, lipid, and ash content. Proximate analysis of raw materials was carried out to determine the chemical composition and total microbial content as a reference or comparison material for the treatment applied in this study.

Table 4. The analysis of the proximateof red snapper fillets treated with Kaffir limes (Citrus hystrix) leaf essential oil

\begin{tabular}{|c|c|c|}
\hline Treatment & 0 Hour & 24 Hours \\
\hline Water content $(\%)$ & 67.10 & 73.44 \\
\hline Protein Content (\%) & 5.36 & 10.5 \\
\hline Fat level (\%) & 0.23 & 0.19 \\
\hline Ash content (\%) & 8.72 & 8.26 \\
\hline
\end{tabular}

\section{DISCUSSION}

The obtained results of the current study showed that the number of total bacteria on red snapper fillets using the TPC method increased from P0 (control) to P1 (1\% essential oil) in the course of the study (from the beginning to 24 hours). The high bacteria in the P1 (1\% essential oil) correlated with the water content of the product. Edible coatings can inhibit water evaporation processes and other volatile compounds in food ingredients leading to the increase of water content in the material (Wijana et al., 2013). The use of carrageenan edible coatings for fresh fish preservatives indicated that the amount of water content in the product can lead to moist conditions, which is suitable for bacterial growth in the fillet (Mursida, 2012). In addition, poor environmental and air conditions also affect the number of bacteria.

Regarding P2 treatment (1.5\% essential oil), the number of bacteria decreased since this essential oil was rich with an antibacterial compound, namely citronellal (Yuliani et al., 2011). Antibacterial activity of kaffir lime leaf essential oil (Citrus hystrix) against Staphylococcus aureus and Escherichia coli could lead to the lysis of bacteria cells (Yuliani et al., 2011). The lysis process occurs due to the different structures of the bacterial cell wall. The bacterial cell wall acts as a cell-forming and protects cells against osmotic lysis. Substances damaging cell walls or blocking synthesis could result in bacterial death. The obtained result of the P3 treatment group (2\% essential oil) was indicative of an increase in bacterial growth. The high content of essential oils induced a lower number of bacteria found in the ingredients (Yuliani et al., 2011).

The $\mathrm{pH}$ value of the red snapper fillets decreased due to the accumulated amount of lactic acid (Stien et al., 2005). The reason for the accumulated lactic acid was the decomposition processing of glycogen in fish meat, and the changing process of glycogen into lactic acid in this regard. The quality decrease of African catfish fillet at chilling temperature and death treatment method indicated that the biochemical changes that occurred in the body tissue after the fish death 
were characterized by the $\mathrm{pH}$ decrease due to the accumulation of lactic acid (Li et al., 2019).

The organoleptic test results related to red snapper fillets with and without the addition of kaffir lime leaf essential oils showed that treatments at null hour could be accepted by the panelists following SNI for minimum organoleptic values of seven. The appearance of red snapper fillets at the null hour was specific color types, bright, fresh smell, and specific types of fish, while the texture was very dense and compact. The solid and compact texture was obtained due to the addition of gelatin to red snapper fillets. Gelatin can change reversibly from solid to gel, swell, or expand in cold water, and form films in terms of mechanical properties (Parker, 1982). Gelatin easily dissolves at $71.1^{\circ} \mathrm{C}$, and turns into a gel at $48.9^{\circ} \mathrm{C}$ (Rahayu and Fithriyah, 2015) meaning that the compact and dense texture of red snapper fillets results from the fact that gelatin is forming into a gel at low temperatures, so it could coat the product well.

The results of the organoleptic-test showed during 24-hour storage, all parameters were acceptable, however, at the minimum limit (value) according to SNI 2717 .1: 2009 which is seven. The appearance at the 24th hour was intact, neat, and the colour was slightly dull in P0. The colour of fish meat turned to fade or dull due to oxidized carotene pigments (Andrés-Bello et al., 2013). The colour fading occurred due to double bond auto acylation, which was the oxidation of bright red myoglobin to brown metmyoglobin causing fish duller (Kelautan and Indonesia, 2018). At the null hour, there was a smell of ammonia, and the red snapper fillets smelled slightly sour since proteins reshuffled into volatile compounds free of decay microbes (Kosowska et al, 2017). The odor was related to the presence of several volatile compounds produced by decomposing bacteria, including Trimethylamine (TMA), sulfide, alcohol, ketones, aldehydes, and organic acids which were responsible for the appearance of fishy smell and ammonia (Gram et al., 2002). Water content in red snapper fillets in P0 and P2 showed an increase at the end of the storage. Edible coatings could inhibit the process of evaporation of water and other volatile compounds of food products, so water content in the material was higher (Wijana, 2013). During the storage at room temperature, the changes of water content resulted from free water formed due to protein degradation by microorganisms. Proteins in red snapper fillets in P0 and P2 showed an increase at the end of the storage since the coating material was gelatin. Gelatin is a simple protein resulting from collagen hydrolysis which makes it easily soluble in water in contrast to collagen (Miskah et al., 2013).

The fat content of red snapper fillets in P0 and P2 showed a decrease at the end of the storage. Kaffir lime leaf essential oil is non-polar, so it could dissolve fat (Khasanah et al., 2015). Fat is an organic compound found in nature that is not soluble in water but can be dissolved in nonpolar organic solvents and a major component is adipose tissue (Arvanitoyannis, 2010).

The ash content of red snapper fillets in P0 and P2 showed a decrease at the end of the storage. Duration of immersion causes the dissolution of mineral compounds (Winarno and Agustinah, 2008). Decreasing ash levels occurred due to the solubility of minerals in water (Winarno and Agustinah, 2008). It was supported that the more minerals are lost, the lower ash content is found in red snapper fillets.

\section{CONCLUSION}

Based on the findings of the current study, it can be concluded that the addition of Kaffir limes (Citrus hystrix) leaf essential oil in gelatin-coating could be used as a method of fishery products processing in extending the shelf life of red snapper fillet at the room temperature and inhibiting bacterial growth.

\section{REFERENCES}

Andrés-Bello A, Barreto-Palacios V, and García-Segovia P (2013). Effect of pH on color and texture of food products. Food Engineering Reviews, 5: 158-170. DOI: https://doi.org/10.1007/s12393-013-9067-2

Arvanitoyannis IS (2010). Irradiation of food commodities: techniques, applications, detection, legislation, safety and consumer opinion. Academic Press, Elsevier. DOI: https://doi.org/10.1016/C2009-0-01843-1

Ayusuk S, Siripongvutikorn S, Thummaratwasik P, and Usawakesmanee W (2009). Effect of heat treatment on antioxidant properties of Tom-Kha paste and herbs/spices used in Tom-Kha paste. Kasetsart Journal-Natural Sciences, 43: 305-312. Available at: https://www.researchgate.net/publication/286850267_Effect_of_heat_treatment_on_antioxidant_properties_of_tomkha_paste_and_herbsspices_used_in_tom-kha_paste

Dance MA, and Rooker JR (2019). Cross-shelf habitat shifts by red snapper (Lutjanus campechanus) in the Gulf of Mexico. Plos One 14(3): e0213506. DOI: https://doi.org/10.1371/journal.pone.0213506

Florensia S, Dewi P, and Utami NR (2012). Pengaruh Ekstrak Lengkuas pada Perendaman Ikan Bandeng terhadap Jumlah Bakteri Pengaruh Ekstrak Lengkuas pada Perendaman Ikan Bandeng terhadap Jumlah Bakteri. Unnes Journal of Life Science, 1: 113118. Available at: https://journal.unnes.ac.id/sju/index.php/UnnesJLifeSci/article/view/995

Gram L, Ravn L, Rasch M, Bruhn JB, Christensen AB, and Givskov M (2002). Food spoilage —interactions between food spoilage bacteria. International Journal of Food Microbiology, 78:79-97. DOI: https://doi.org/10.1016/S0168-1605(02)00233-7

Harris GK, and Marshall MR (2017). Ash analysis. In Food analysis. Springer, Cham. pp. 287-297. DOI: https://doi.org/10.1007/9783-319-45776-5_16

Hart FL, and Fisher HJ (1971). Modern Food Analysis. Springer, Berlin, Heidelberg, pp 176-219, and 284-307. Available at: https://link.springer.com/book/10.1007/978-3-642-87521-2 
Indrasti NS, Suprihatin D, and Setiawan WK (2012). Kombinasi kitosan-ekstrak pala sebagai bahan antibakteri dan pengawet alami pada filet kakap merah (Lutjanus sp Kombinasi Kitosan-Ekstrak Pala seb, 22: 122-130. Available at: https://jurnal.ipb.ac.id/index.php/jurnaltin/article/download/6725/5195

Jongjareonrak A, Benjakul S, Visessanguan W, Prodpran T, and Tanaka M (2006). Characterization of edible films from skin gelatin of brownstripe red snapper and bigeye snapper. Food Hydrocolloids, 20: 492-501. DOI: https://doi.org/10.1016/j.foodhyd.2005.04.007

Kelautan K, and Indonesia PR (2018) Statistik Kelautan dan Perikanan. Jakarta KKP, Jakarta. Available at: https://kkp.go.id/wpcontent/uploads/2018/01/KKP-Dirjen-PDSPKP-FMB-Kominfo-19-Januari-2018.pdf

Khasanah LU, Kawiji K, Utami R, and Aji YM (2015). Pengaruh Perlakuan Pendahuluan Terhadap Karakteristik Mutu Minyak Atsiri Daun Jeruk Purut (Citrus hystrix DC). Jurnal Aplikasi Teknologi Pangan, 4: 48-55. Available at: http://www.jatp.ift.or.id/index.php/jatp/article/view/98/64

Kosowska M, MAjcher A, and Fortuna T (2017). Volatile compounds in meat and meat products. Food Science and Technology, 37(1): 1-7. DOI: https://doi.org/10.1590/1678-457x.08416

Li Y, Wu C, Wu T, Yuan C, and Hu Y (2019). Antioxidant and antibacterial properties of coating with chitosan-citrus essential oil and effect on the quality of Pacific mackerel during chilled storage. Food Science and Nutrition, 7: 1131-1143. DOI: https://doi.org/10.1002/fsn3.958

López-Caballero ME, Martínez-Álvarez Ó, Gómez-Guillén MC, and Montero P (2006). Effect of natural compounds alternative to commercial antimelanosics on polyphenol oxidase activity and microbial growth in cultured prawns (Marsupenaeus tiger) during chilled storage. European Food Research and Technology, 223: 7-15. DOI: https://doi.org/10.1007/s00217-005-0049-3

Miskah S, Ramadianti IM, and Hanif AF (2013). Pengaruh Konsentrasi CH3COOH \& Hcl Sebagai Pelarut Dan Waktu Perendaman Pada Pembuatan Gelatin Berbahan Baku Tulang/Kulit Kaki Ayam. Journal of Tekniks Kimiya, 17: 1-18. Available at: http://jtk.unsri.ac.id/index.php/jtk/article/view/97

Munda M (2013). Pengaruh Konsentrasi Asam Asetat Dan Lama Demineralisasi Terhadap Kuantitasdan Kualitas Gelatin Tulang Ayam. Universitas Hasanuddin - Fakultas Peternakan (Animal Husbandary), Makassar. Available at: https://core.ac.uk/download/pdf/25493929.pdf

Mursida M (2012). Penggunaan lapisan edibel dari karagenan sebagai bahan pengawet ikan segar. Journal of Galung Tropicals, 2012, article id: 2. Available at: http://repository.ub.ac.id/id/eprint/149992

Parker A (1982). Principles of Biochemistry. Sparkas, Maryland: Worth Publishers, Wiley, UK. DOI: https://doi.org/10.1016/0307$\underline{4412(83) 90020-1}$

Rahayu F, and Fithriyah NH (2005). Pengaruh Waktu Ekstraksi Terhadap Rendemen Gelatin dari Tulang Ikan Nila Merah. Seminar Nasional Sains dan Teknologi, 6: 1-6. Available at: https://jurnal.umj.ac.id/index.php/semnastek/article/download/447/413

Shahiri Tabarestani H, Sedaghat N, Jahanshahi M, Motamedzadegan A and Mohebbi M (2016) Physicochemical and rheological properties of white-cheek shark (carcharhinus dussumieri) skin gelatin. International Journal of Food Properties, 19: 2788-2804. DOI: https://doi.org/10.1080/10942912.2015.1050595

Siburian HP (2015). Aplikasi Edible Coating Aloe vera Kombinasi Ekstrak Jahe pada Buah Tomat Selama Penyimpanan . Ph.D thesis in Universitas Lampung, Lampung. Available at: https://adoc.pub/aplikasi-edible-coating-aloe-vera-kombinasi-ekstrak-jahepad.html

Sohaib M, Anjum FM, Arshad MS, and Rahman UU (2016). Postharvest intervention technologies for safety enhancement of meat and meat based products; a critical review. Journal of food Science and Technology, 53(1): 19-30. DOI: https://doi.org/10.1007/s13197-015-1985-y

Souza BW, Cerqueira MA, Ruiz HA, Martins JT, Casariego A, Teixeira JA, and Vicente AA (2010). Effect of chitosan-based coatings on the shelf life of salmon (Salmo salar). Journal of Agricultural and Food Chemistry, 58(21): 11456-11462. DOI: https://doi.org/10.1021/jf102366k

Standar Nasional Indonesia (1992). Standar Nasional Indonesia 02-2725. Batas Minimum Cemaran Mikroba Pada Daging, Dewan Standardisasi Nasional, Jakarta. Available at: http://www.bkipm.kkp.go.id/bkipmnew/sni/index/PRODUK\%20PERIKANAN

Stien LH, Hirmas E, Bjørnevik M, Karlsen $\emptyset$, Nortvedt R, and Rørå AMB (2005). The effects of stress and storage temperature on the colour and texture of pre-rigor filleted farmed cod (Gadus morhua L.). Aquacultural Research, 36: 1197-206. DOI: https://doi.org/10.1111/j.1365-2109.2005.01339.x

Wijana S, Sucipto, and Sari LM (2013). Effect Of Temperature and Drying Time On Antioxidant Activity In Mangosteen Rind Powder (Garcinia Mangostana L.). Jurnal Ilmu dan Teknologi Pangan, 36: 57-64. Available at: https://adoc.pub/pengaruh-suhudan-waktu-pengeringan-terhadap-aktivitas-antio.html

Winarno FG, and Agustinah W (2008). Peran Pangan Dan Autism, Jakarta University Press, Jakarta. 